\title{
CONTEMPORARY CHANGES IN THE RELIEF OF RAISED BOGS ON THE EXAMPLE OF THE POLISH CARPATHIANS
}

\author{
ADAM ŁAJCZAK \\ Institute of Geography, Jan Kochanowski University, \\ ul. Świętokrzyska 15, 25-406 Kielce, Poland \\ E-mail: alajczak@o2.pl
}

\begin{abstract}
The subject of this paper is the problem of anthropogenic changes in the relief of raised bogs in mountain areas. This problem has not received a great deal of attention in the research literature. All peat bogs in the Polish part of the Orawa - Nowy Targ Basin and the Bieszczady Mountains were analysed. Special attention was paid to the remnants of peat domes and post-peat areas and the scarps separating them. This paper is based on an analysis of maps produced over the last 230 years as well as aerial photographs. Field data were also analysed as part of this research. Six phases in the development of scarps were identified. The rate of relief change was estimated and the role of exposure was assessed. Attention was paid to changes in the relief of post-peat areas that are occurring because retention ponds and drainage ditches have become more shallow due to beaver activity and the results of stream channel regulation. Special attention was also paid to the geomorphological aspects of the restoration of post-peat areas.
\end{abstract}

Key words: anthropopression, raised bog, peat dome, post-peat area, the Orawa - Nowy Targ Basin, the Bieszczady Mountains, the Carpathian Mountains

\section{OUTLINE OF THE PROBLEM}

Contemporary changes in the relief of anthropogenically altered peat bogs, and especially raised bogs in mountain areas, are rather rarely discussed in the literature versus currently observed changes in the physical and chemical properties of peat deposits that indicate pollution in the environment (e.g., Bindler, 2006; Coggins et al., 2006; Fiałkiewicz-Kozieł, 2009). In terms of present-day changes, some of the best examples are the peat bogs of Great Britain and Ireland, where much attention is paid to the decline of blanket bogs due to sheep grazing, peat burning, water drainage systems, and to a lesser degree, peat extraction (Bower, 1961; Mallik et al., 1984; Evans, 1989; Shaw et al., 1997; Bragg and Tallis, 2001). Publica- tions on the human impact on peat bogs pay a lot of attention to peat erosion but a more detailed analysis of changes in the peat bog relief is omitted (Cooper and McCann, 1995).

Compared to other areas of the world, the level of knowledge on anthropogenic changes in the relief of peat bogs in some areas of Poland may be considered advanced. This applies not only to peat bogs in northern Poland but also southern Poland, where peat bogs are also found. Peat bogs are most numerous in northern Poland, where peat is extracted on an industrial scale across large areas in which peat deposits are first dried. The best analysed peat bogs in southern Poland are the raised bogs of the Orawa - Nowy Targ Basin (Jasnowski, 1975; Żurek, 1987; Koczur, 1996; Łajczak, 2002, 2006a). Three 


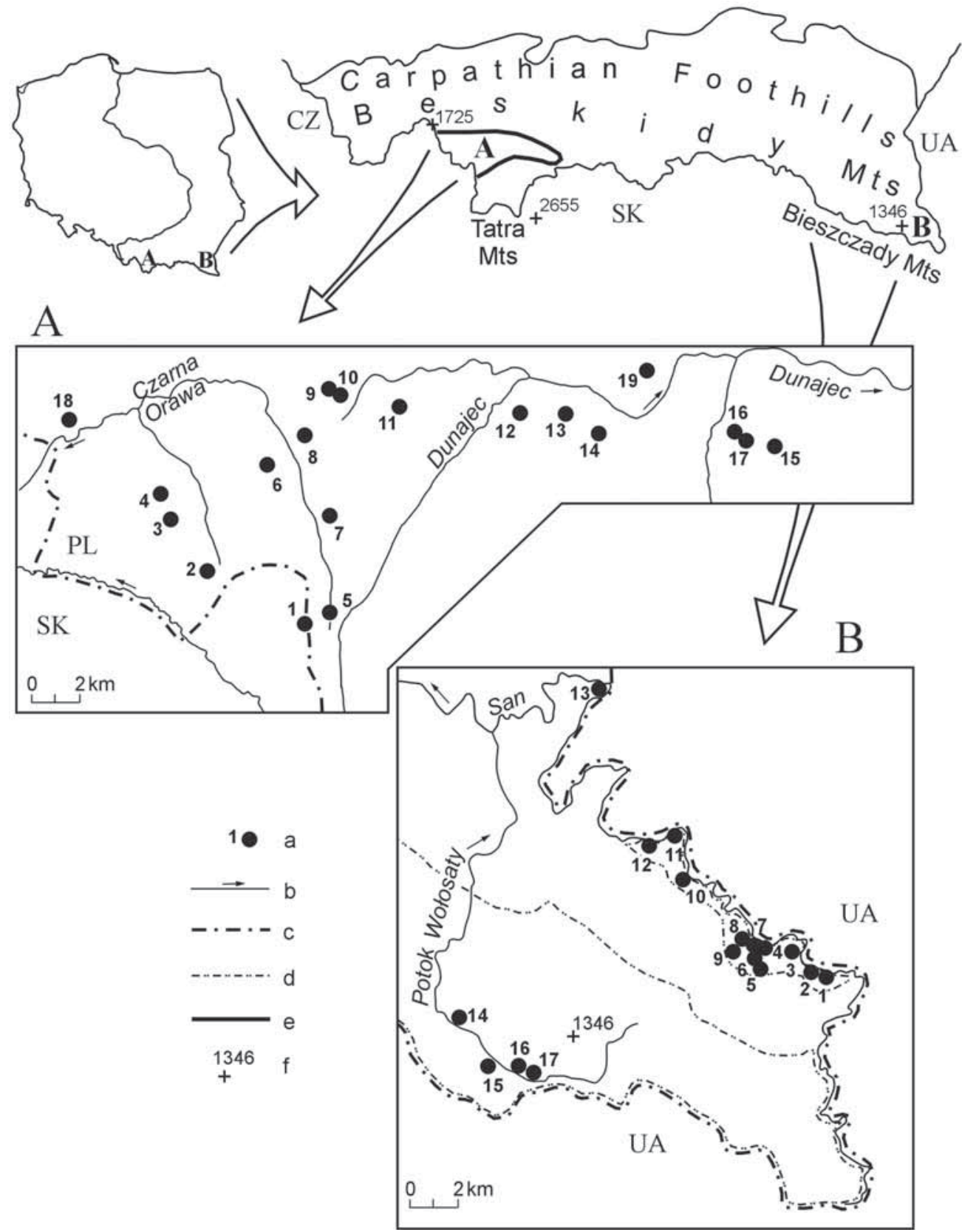

Figure 1. Distribution of the investigated raised bogs within the Polish part of the Orawa - Nowy Targ Basin (A) and the Bieszczady Mountains (B)

$\mathrm{a}$ - raised bogs and their numbering, b - main water courses, $\mathrm{c}$ - state border, $\mathrm{d}$ - border of the Bieszczady National Park, e - limit of the Orawa - Nowy Targ Basin in Poland, f - main culminations. CZ - Czech Republic, PL - Poland, SK -Slovakia, UA - Ukraine 
stages in the geomorphological development of raised bogs in the Orawa - Nowy Targ Basin are distinguished (Lajczak, 2005): (1) growth of peat domes, (2) human impact on peat bogs, (3) restoration of preserved fragments of peat bogs. As peat domes grow, depressed terrain becomes fossilized, where the process of peat creation begins just as it does in other areas (Kaule and Göttlich, 1976). The second stage is shorter than the first stage and it may have begun in historical times or quite recently. Peat burning, peat extraction and water drainage networks limit the size of peat domes and cause their fragmentation or even destruction in some cases. In effect, the size of post-peat areas increases and physical changes may cover large areas of peat deposit degradation (Koczur, 1996; Łajczak, 2002, 2006a).

The dominant landscape element of post-peat areas are scarps, which are created where peat extraction takes place. Scarps are initially vertical or step-like type, often forming zigzag-shaped sequences. Another important landscape element are numerous hollows filled with water. Older post-peat areas, deprived of peat cover, are used for agriculture (Mirska, 1956). The landforms that were hidden underneath peat deposits in such areas become exposed to view as current features of terrain. The peat layer remains preserved in younger post-peat areas, but its thickness is greatly reduced with respect to the original. Younger post-peat areas are more frequently drained by man-made drainage systems than older post-peat areas. Active peat extraction fields that are being intensively dried possess the most diverse and dynamic morphology. The third stage in peat bog development begins after peat extraction ends. Once peat extraction ends and the drying of the remaining peat deposits is discontinued, the landscape of a post-extraction peat bog is changed and the thickness of the remaining peat deposits is greatly reduced. This is how peat bogs become post-peat areas. A decrease in the geomorphological contrasts in post-peat areas along with an increase in water content within the remaining peat cover are typical aspects of the third stage of peat bog development.

The raised bogs of the Polish Carpathians, located in the Orawa - Nowy Targ Basin and in the Bieszczady Mountains (Fig. 1) were selected for detailed analysis.

\section{SCOPE AND PURPOSE OF RESEARCH AND MATERIALS USED}

The surface area of selected raised bogs as well as their total surface area within the study area were estimated. The estimates reflected the most likely values of the areas for the period prior to human impact. The present-day surface areas of the remnants of peat domes as well as younger and older post-peat areas were also estimated. According to Myślińska (2001), the total area of a peat bog includes its dome (or the remnants of a dome) and post-peat areas with a surface area exceeding 0.5 ha, with an average thickness of the peat deposit exceeding $20 \mathrm{~cm}$. All younger post-peat areas analysed in this paper met these criteria. The length, height and slope of peat scarps were calculated. The amount of plant cover on scarps was determined during the last 10 years. Multiple vertical cross-section samples were collected from scarps in order to obtain morphological profiles. An inventory of drainage ditches was taken in post-peat areas, and the density of ditches per unit area was calculated along with other descriptive parameters. These included the depth and width of ditches, the slope of their scarps, the amount of plant cover and water depth. Similar calculations were performed for the channels of streams draining peat bogs as well as larger natural or regulated streams in the general vicinity. The distribution of hollows in younger post-peat areas was also determined, as were the vertical and horizontal dimensions of hollows and the amount of plant cover within them.

The purpose of this paper is to describe the rate of shrinkage in the surface area of peat domes in selected areas in the Polish Carpathian Mountains. Peat dome surfaces 
have been shrinking since the middle of the $19^{\text {th }}$ century, in addition to earlier changes. A second purpose is to describe the rate of growth in the surface area of older and younger post-peat areas. With that in mind, the direction and rate of change of landforms typical of younger post-peat areas, such as peat extraction scarps, post-extraction hollows, drainage systems including ditches and regulated stream channels, were analysed in detail. A special emphasis was placed on the period of time when the restoration of such areas has taken place.

The paper is based on an analysis of maps produced over the last 230 years (years: 1780 , $1855,1879,1900,1934,1965,1978,1996)$ as well as on aerial photographs taken in 1965, 1988 and 2006. Field data were also analysed. The fieldwork included geomorphological mapping of specified landforms within peat bogs using GPS techniques and morpho- metric terrain data from the last 15 years. Information obtained from local water management authorities and other institutions as well as information gathered by interviewing individuals involved in peat extraction for many years were also included in this research. Information from the research literature on the subject was considered as well.

\section{STUDY AREA}

There are 19 remnant peat domes in the Polish part of the Orawa - Nowy Targ Basin. They are of a different size and are surrounded by younger post-peat areas (Fig. 1). The domes can be found at an elevation of 592-770 $\mathrm{m}$ and stretch across the Mindel and post-glacial terraces, rising between $30-$ $40 \mathrm{~m}$ and $5-10 \mathrm{~m}$, respectively, over the channels of the Czarny Dunajec, Biały Dunajec
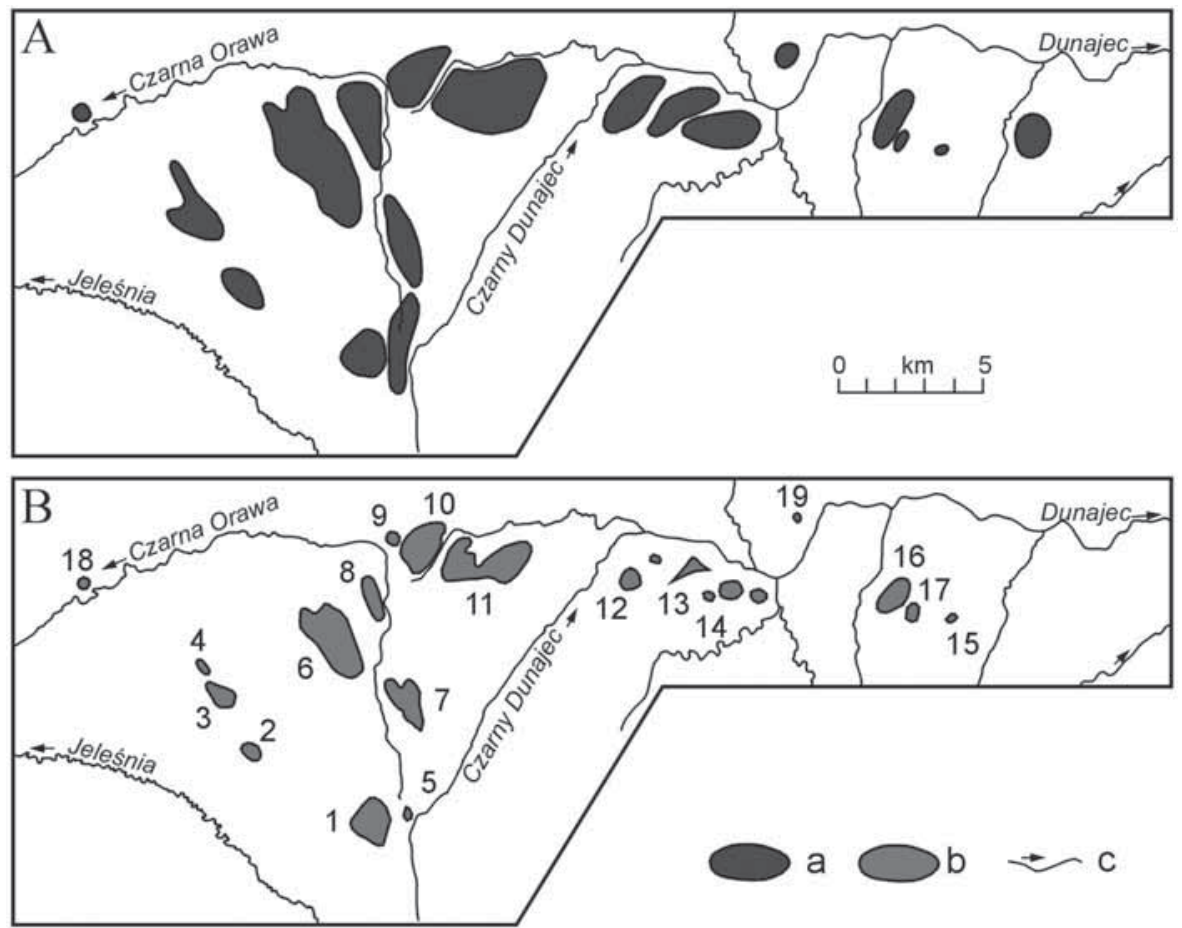

Figure 2. Probable limit of peat domes in the Polish part of the Orawa - Nowy Targ Basin in the period prior to human activity in this area (A) and recent limit of remnants of peat domes (B) 
and Czarna Orawa rivers (Łajczak, 2006a). Peat bogs developed on a poorly permeable layer of clay atop gravel. Bog development is aided by a cool and humid climate, with precipitation at about $1,000 \mathrm{~mm}$. Only one peat bog can be classified as ombrotrophic, with others being recharged by groundwater outflows. In the Polish part of the Bieszczady Mountains, there are 17 raised bogs located in valleys. Thirteen of the bogs are located in the upper valley of the San River, while four are located in the Wolosatka Valley (Fig. 1). The peat domes in this area are smaller than those in the Orawa - Nowy Targ Basin and are surrounded by a narrow zone of younger post-peat areas. They are located at an elevation of 550-700 $\mathrm{m}$ and occupy a post-glacial terrace and alluvial fans, rising 5-8 m over river channels. The bogs' base material is a layer of loam atop gravel. Precipitation in this area ranges from 1,000 to $1,200 \mathrm{~mm}$. Once again, most of the valley peat bogs are recharged by groundwater outflows (Łajczak, 2011).

\section{RESULTS}

\section{A DECREASE IN THE EXTENT OF PEAT DOMES} AND AN INCREASE IN POST-PEAT AREAS UNTIL THE BEGINNING OF THE 21ST CENTURY

The probable range of peat domes in the Polish part of Orawa - Nowy Targ Basin prior to the era of human activity was estimated based on traces of old peat bogs as well as old maps of peat bog areas and the geomorphological situation in the region (Lajczak, 2006a). The contemporary peat bog range differs markedly from the historical range (Fig. 2). On the other hand, peat bog domes in the Bieszczady Mountains were only somewhat larger prior to the era of human activity than they are today (Lajczak, 2011). For this reason and because they are rather small to begin with, their historical and current range was not presented. The total peat dome area in the Orawa - Nowy Targ Basin is estimated to have been about 3,500 ha at the time and the area of low peat bogs is estimated to have been at least 15,000 ha at the time. The total area of valley peat domes in the Bieszczady Mountains was only 56 ha. The area of valley low peat bogs was most likely similar.

Detailed maps make it possible to establish the rate of decline in the total area of peat domes in the Orawa - Nowy Targ Basin starting in 1780 . It is likely that the decline began as early as the $13^{\text {th }}-17^{\text {th }}$ centuries when settlers arrived in the region (Fig. 3). The peat dome range decreased at the highest rate in the $19^{\text {th }}$ century and the first half of the $20^{\text {th }}$ century. In recent years, the peat dome range has begun to stabilize due to reduced interest in peat bog extraction and reduced water management efforts. This has led to clearly visible restoration of post-peat areas (Łajczak, 2002). At this time, rem-

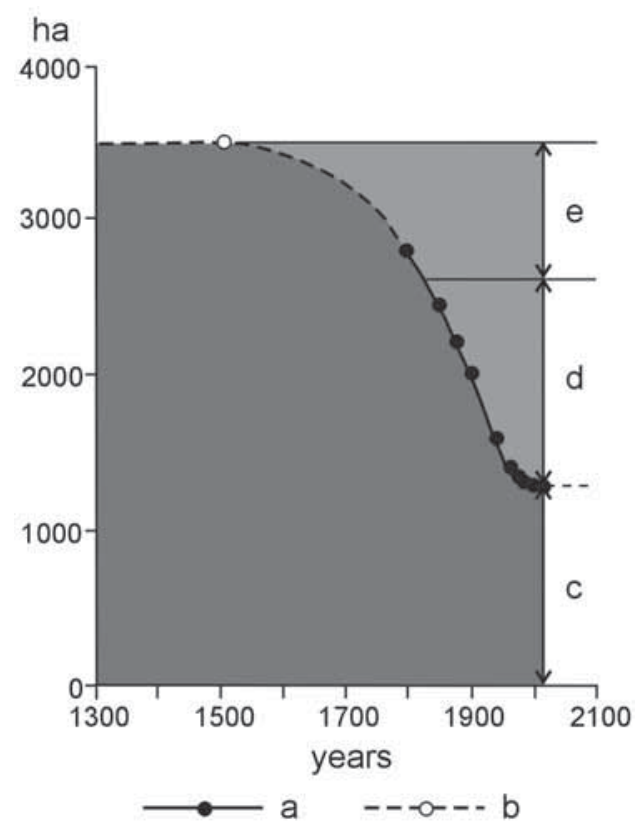

Figure 3. Decreasing of total area [ha] of peat domes in Polish part of the Orawa - Nowy Targ Basin in the period of over 400 years until the beginning of the $21^{\text {st }}$ century

$\mathrm{a}$ - area calculated on the basis of maps and aerial photographs, b - area estimated on the basis of other sources of information, c - total area of peat domes, $\mathrm{d}$ - total area of younger post-peat areas, e - total area of older post-peat areas (only within former peat domes) 

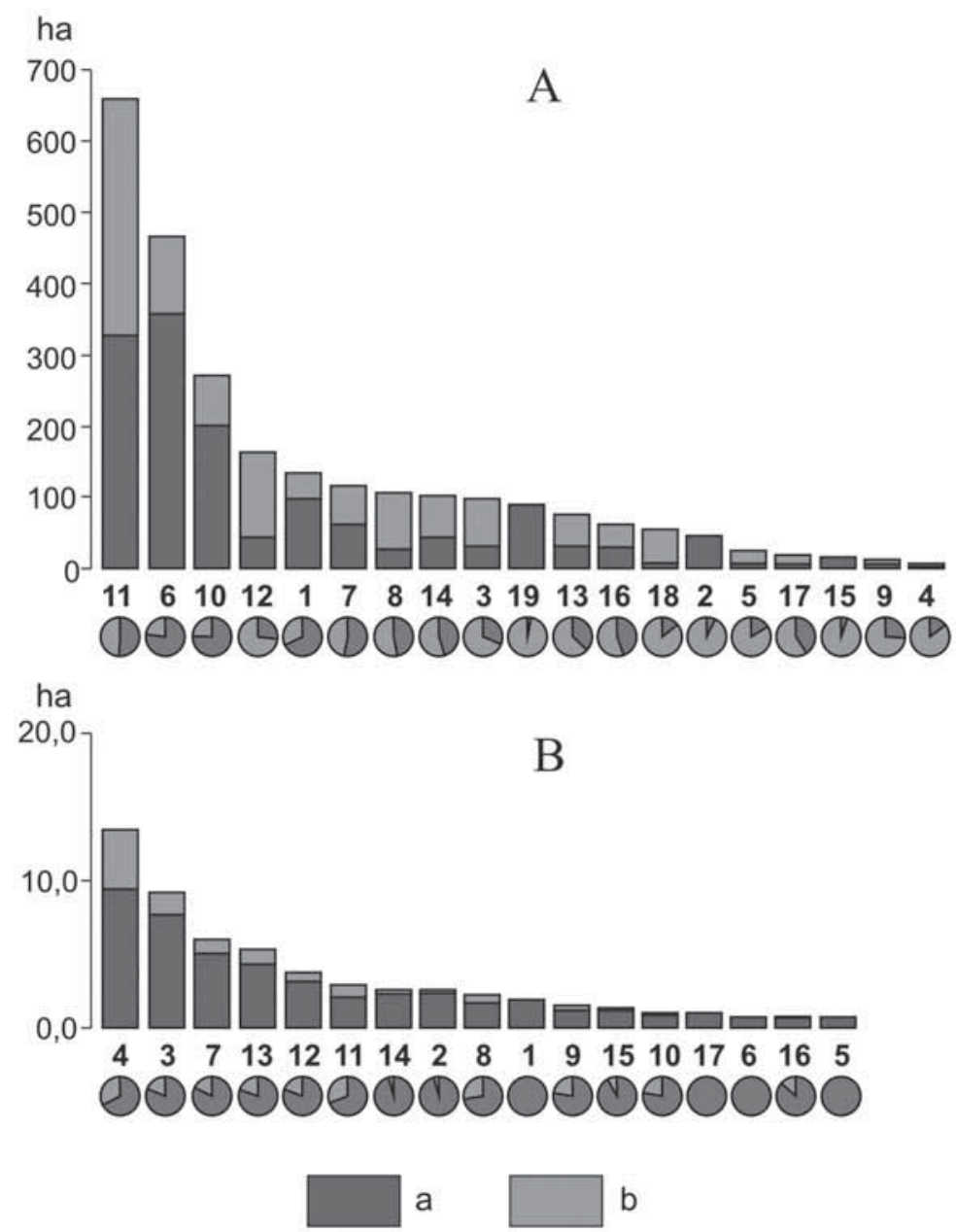

Figure 4. Area [ha] of individual raised bogs and additionally area occupied by remnants of peat domes and younger post-peat areas in Polish part of the Orawa - Nowy Targ Basin (A) and Bieszczady Mountains (B)

Participation [\%] of remnants of domes and post-peat areas in total area of individual raised bogs (circle diagrams): $\mathrm{a}$ - remnants of peat domes, $\mathrm{b}$ - younger post-peat areas. Numbering of peat bogs like in Fig. 1

nants of peat domes occupy 1,300 ha in the basin, which is about $37 \%$ of their original area. In addition, they are surrounded by younger post-peat areas that occupy 1,250 ha in the basin. Older post-peat areas located in fully extracted peat domes occupy a slightly smaller area. The area of older post-peat areas in former low peat bogs is at least 10 times greater. Today, low peat bogs cover an area of over 5,000 ha (Łajczak, 2006a).
The total area of peat domes in the Polish part of the Bieszczady Mountains (47 ha) is now 28 times smaller than that in the Orawa - Nowy Targ Basin. The Bieszczady Mountains' peat dome range is currently $84 \%$ of its original size. The younger post-peat areas that surround them cover only 9 ha. Most of the younger post-peat areas had evolved as a result of peat extraction and not the drying of the base material. There is a lack of 
information on how human activity had affected the Bieszczady peat bogs prior to the middle of the $19^{\text {th }}$ century, which makes it impossible to know if older post-peat areas had existed in the region (Lajczak, 2011). The period of time believed to be responsible for the reduction in the range of peat domes and the formation of post-peat areas began in the middle of the $19^{\text {th }}$ century and ended in the 1980s. Peat bog reserves were then established in the region. Finally, most peat bogs were annexed by the Bieszczady National Park and the process of restoration began.

Peat bogs in the Orawa - Nowy Targ Basin vary in size much more than do peat bogs in the Bieszczady Mountains. In the former, there are 19 peat bogs and they range in size from 9 to 660 ha (Fig. 4A). In 15 of the 19 peat bogs, younger post-peat areas occupy an area larger than that of the remnants of peat domes. In 9 of the 15 peat bogs, post-peat areas occupy as much as $70 \%$ of the total peat bog area. In only two large peat bogs (Puścizna Wielka - No 6 in Fig. 1, Baligówka - No 10 in Fig. 1) do peat domes occupy over $70 \%$ of the total peat bog area. Peat bogs in the Bieszczady Mountains occupy areas ranging from 0.8 to 13.5 ha (Fig. 4B). In each case, post-peat areas are much smaller than peat domes and cover up to $30 \%$ of peat bog areas. In most cases, post-peat areas cover no more than $20 \%$ of peat bog areas. Four peat bog areas in the Bieszczady Mountains have no post-peat areas.

\section{DISTRIBUTION OF PEAT EXTRACTION SCARPS AND THE RATE OF CHANGE IN THEIR SHAPE}

The most characteristic element of relief in peat bogs affected by human activity are scarps separating fragments of untouched peat domes from extraction areas and younger post-peat areas. Peat bog scarps can be found both in the Bieszczady Mountains and in Orawa - Nowy Targ Basin, however, they are more readily visible in the latter. Scarps also form in the fringe zones of water management areas, where they separate lower areas of dried peat from those saturated with water. This may also explain the origin of peat bog scarps in the Bieszczady Mountains, although the more likely explanation is the extraction of peat years ago. In most cases, the remnants of a peat dome are encircled by one wall-type or step-type scarp. In some cases, two or more scarps can be found. In the case of fragmented peat domes, the scarp system tends to be complex (e.g., Przymiarki peat bog - No 14 in Fig. 1). The peat bog scarp system tends to be even more complex when an untouched part of the peat bog is used as an access ramp leading to the extraction area. In most cases, the ramp is perpendicular to the main scarp. This is the case at the Puścizna Rękowiańska peat bog (No 11 in Fig. 1).

Peat bog scarps usually form as a result of peat extraction along the edge of the peat dome. When the work area moves towards the middle of the peat bog, the height of the scarp increases. In the Orawa - Nowy Targ Basin, fresh scarps reached in the middle of the $20^{\text {th }}$ century the height of $6 \mathrm{~m}$ (Korczyńska, 1952; Mirska, 1956; Jostowa ,1963). Peat extraction by local landowners has led to the formation of zigzag-type scarps. Younger post-peat areas featuring a reduced peat layer with an uneven surface can be found on the outside of a scarp. When the lagg fen zone and the edges of raised bogs are part of water management systems, the surface of the partially dried peat bog becomes lowered. This leads to the formation of morphological feature called a gentle scarp. Peat extraction in the two study areas took place also in the centre of the peat dome. The middle of the peat dome becomes hollowed out due to peat extraction and is surrounded by one or more scarps, outside of which peat bog remnants can be found (e.g., Puścizna Rękowiańska peat bog - No 11 in Fig. 1). The morphology of peat bogs affected by human activity is most diverse when peat extraction occurs both inside the dome and along its edges. In each case, dome remnants take the form of narrow peat islands surrounded by post-peat areas featuring multiple hollows that become filled with water once water management systems stop functioning. Large peat 

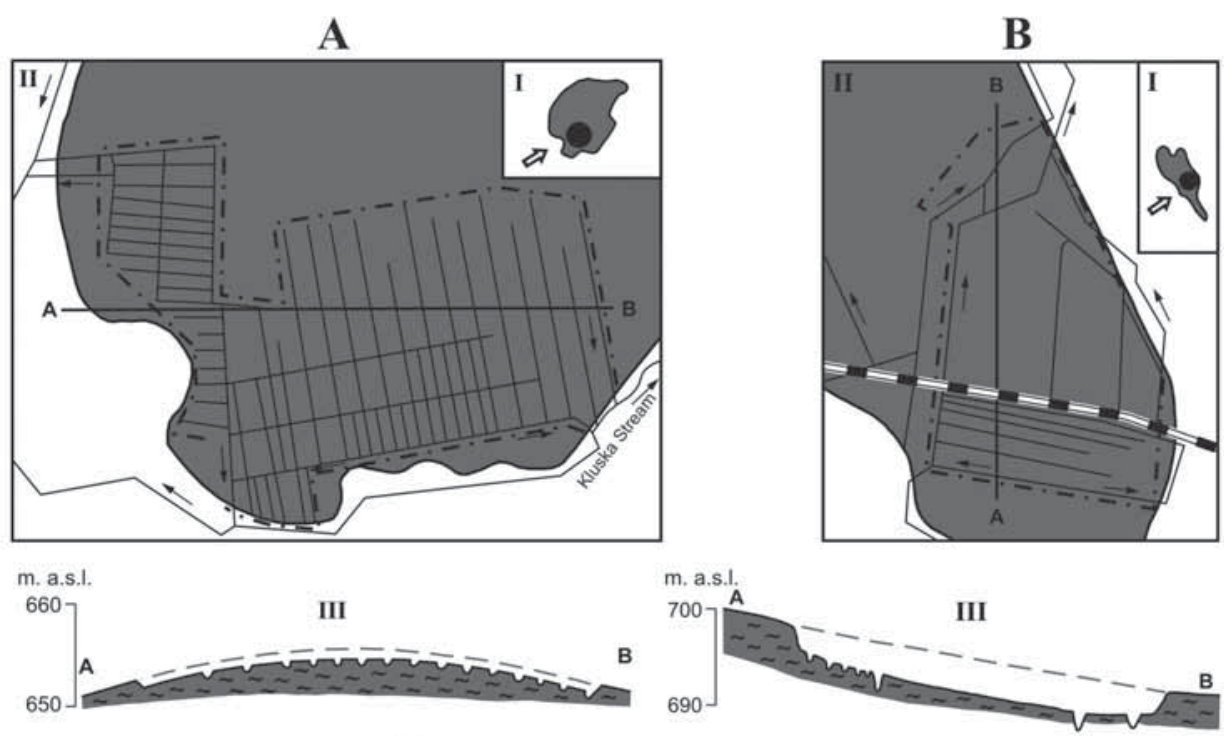

C
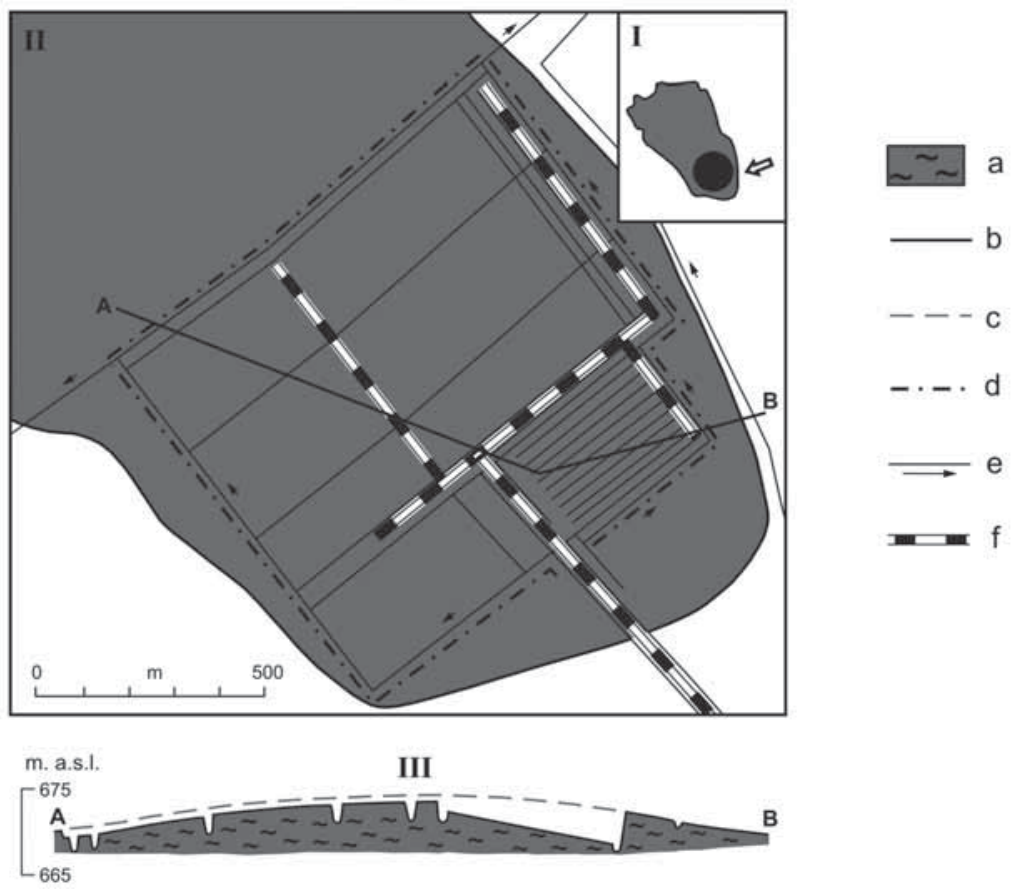

Figure 5. Limit of large peat extraction areas within peat domes in the Orawa - Nowy Targ Basin: Baligówka peat bog, No 10 (A), Bór za Lasem Kaczmarka peat bog, No 7 (B) (both long inactive) and Puścizna Wielka peat bog, No 6 (C) (still active).

I - location within a peat dome, II - plan, III - cross-section (course of line A-B is presented in part II): a - peat deposit, $\mathrm{b}$ - horizontal range of peat dome, $\mathrm{c}$ - former vertical range of peat dome, $\mathrm{d}$ - boundary of extraction area, $\mathrm{e}-$ drainage ditches and drainage directions, $\mathrm{f}$ - narrow-track railway. Numbering of peat bogs like in Fig. 1 
extraction areas can be found within three peat bogs in the Orawa - Nowy Targ Basin: Baligówka, Bór za Lasem Kaczmarka (long inactive), and Puścizna Wielka (still active) (Fig. 5).

The total length of young extraction scarps, post-extraction scarps and scarps resulting from the partial drying of the peat base is $60.7 \mathrm{~km}$ in the Orawa - Nowy Targ Basin, while in the Bieszczady Mountains it is only $6.2 \mathrm{~km}$. Scarps are always found along with younger post-peat areas and active extraction areas whose total area in the Orawa - Nowy Targ Basin is $13.7 \mathrm{~km}^{2}$, of which 13 $\mathrm{km}^{2}$ are younger post-peat areas and $0.7 \mathrm{~km}^{2}$ are active extraction areas. In the Bieszczady Mountains, the corresponding total area is $0.09 \mathrm{~km}^{2}$. In the Orawa - Nowy Targ Basin, there is an average of 22.6 ha of younger post-peat areas per $1 \mathrm{~km}$ of scarp. In the
Bieszczady Mountains, the corresponding value is 1.5 ha. Younger post-peat areas of varying size form along peat bog scarps and their average width in the Orawa - Nowy Targ Basin is $226 \mathrm{~m}$, while in the Bieszczady Mountains it is only $15 \mathrm{~m}$.

Since peat extraction has been halted in the Orawa - Nowy Targ Basin (Fig. 6), rapid changes in peat bog scarp relief can be observed. Old photographs show vertical peat walls (phase "a") that later evolved into different types of scarps and gently sloping dome sides (phases "b"-“f”). This type of evolution of scarp relief has been confirmed by individuals who extract peat in the area. The drying of peat within scarp walls leads to the formation of fractures parallel to the scarp edge, with a depth of up to $2 \mathrm{~m}$ (phase "b"). The sliding of peat packets leads to scarp recession. In addition, rainfall in the

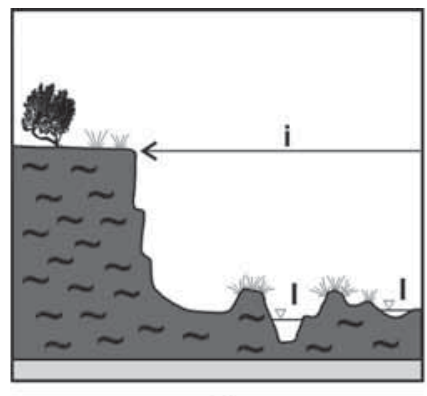

a

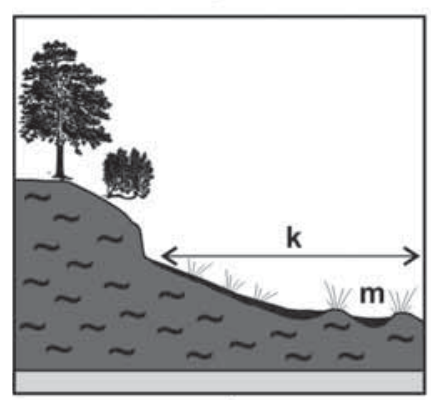

d

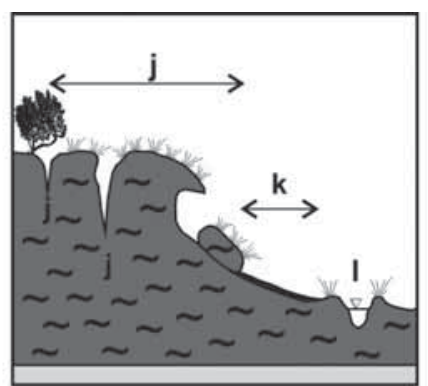

b

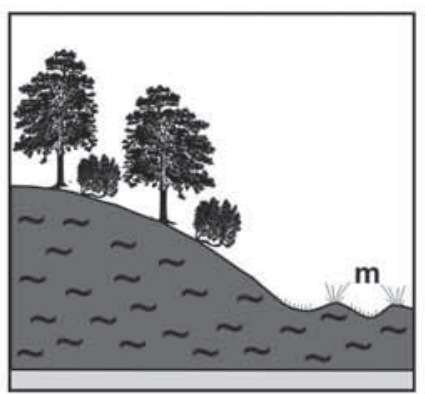

e

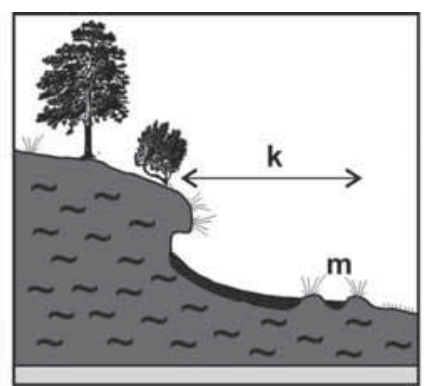

C

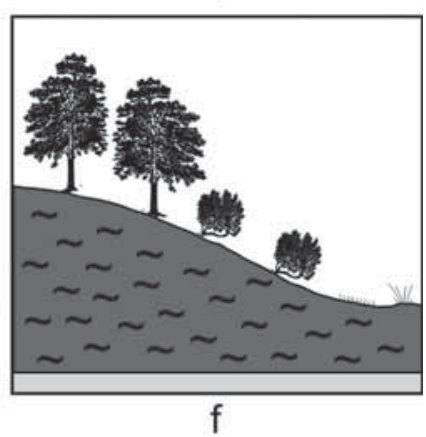

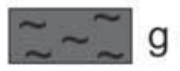

$\mathrm{h}$

Figure 6. Changes in relief of peat bog scarp since peat extraction is halted

$\mathrm{a}-\mathrm{f}$ - phases in scarp transformation, $\mathrm{g}$ - peat deposit, $\mathrm{h}$ - clayey substratum, $\mathrm{i}$ - younger post-peat area, $\mathrm{j}$ - bog slides, $\mathrm{k}$ - bogflows, 1 - peat hollows with water, $\mathrm{m}$ - shallowed hollows without water 
early spring causes peat packets to turn to mud and fill peat hollows at the base of the scarp. Peat hangs over an ever smaller scarp and may fall down over time (phase "c"). As long as a scarp remains partially free of vegetation, it continues to flatten (phase "d"). An old scarp that is completely covered by vegetation assumes a convex-concave shape with a gentle slope (phase "e"). The scarp profile becomes even more gentle over time as a result of the filling of hollows in post-peat areas and an increase in the amount of base material (phase "f").

Less photographic documentation is available for peat bogs in the Polish part of the Bieszczady Mountains than for the Orawa - Nowy Targ Basin. Furthermore, there are no descriptions of land use in peat bog areas in the Bieszczady Mountains. The local population was resettled to a different part of Poland in the late 1940s, which means that there is a lack of local accounts of the appearance of peat bogs prior to the 1940s. There are some data that suggest that some peat bogs in the Bieszczady Mountains had been dried. This was especially true of the edges of peat domes in the second half of the $19^{\text {th }}$ century. This conclusion has been drawn primarily on maps of old water management systems. Most peat bogs in the Bieszczady Mountains were dried to a substantial extent in the 1970s and 1980s (Lajczak, 2011). It is not clear at this point, if the gentle peat bog scarps are primarily the result of the advanced evolution of old vertical peat walls or the result of compaction of dried peat in areas subject to water drainage over 20 years ago. In both cases, the current scarp form may be compared to phases "d" - "f" shown in Fig. 6. Based on the shape of post-extraction scarps in both study areas, it may be inferred that the principal cause of the formation of old peat bog scarps in the Bieszczady Mountains was peat extraction. The drying of peat bogs as part of water management efforts in the 1970s and 1980s had only slightly altered peat bog relief, which had developed prior to the late 1940s (Eajczak, 2011).

In the Orawa - Nowy Targ Basin, the most common scarp development phase is phase "d" (33\% of scarp length). Both younger and older phases account for less scarp length. Only $8 \%$ of scarp length is due to phase "a", while phase "f" accounts for $6 \%$. In the Bieszczady Mountains, phase "e" accounts for $41 \%$ of scarp length, phase "d" accounts for $33 \%$ of scarp length, and phase "f" accounts for $26 \%$ of scarp length.

Maps, photographs and conversations with individuals involved in peat extraction were considered as part of the research study. In the Orawa - Nowy Targ Basin, peat extraction came to an end ten years ago and today most peat bog scarps remain in the form of vertical walls. In general, the more time has passed since the end of peat extraction, the more mature the scarp form is. Phase "c" dominates scarp development for the first 30 years following the end of peat extraction. The next 30 years is dominated by phase " $\mathrm{d}$ ". Phase "e" begins 60 years following the end of peat extraction. A mature convex-concave slope profile of a peat dome remnant forms no earlier than 60 years following the end of peat extraction. In the Orawa - Nowy Targ Basin, en example of peat dome remnant with a highly altered vertical scarp is Bór na Czerwonem (No 16 in Fig. 1) (Fig. 7). In the first half of the $20^{\text {th }}$ century, vertical scarps marking the edges of younger post-peat areas in Bór na Czerwonem were as high as $6 \mathrm{~m}$. The peat bog reserve "Bór na Czerwonem" was enlarged in 1956 and now encompasses the entire peat dome (Lajczak, 2006b). Over the course of the last 54 years, the peat dome scarp has reached phases " $d$ ", "e" and "f" over most of its length.

If it can be assumed that peat extraction was the principal cause behind the formation of peat bog scarps in the Polish part of the Bieszczady Mountains, then the initial phase of their development must be placed over 60 years ago. In light of this, the current state of the scarps must be designated as phases "d" to " $\mathrm{f}$ ", with phase "e" being the dominating phase. However, in light of enhanced water management efforts designed to dry the peat bogs, new scarp development and the rejuvenation of older scarps must be traced back to the 1970s and 1980s. Scarps 


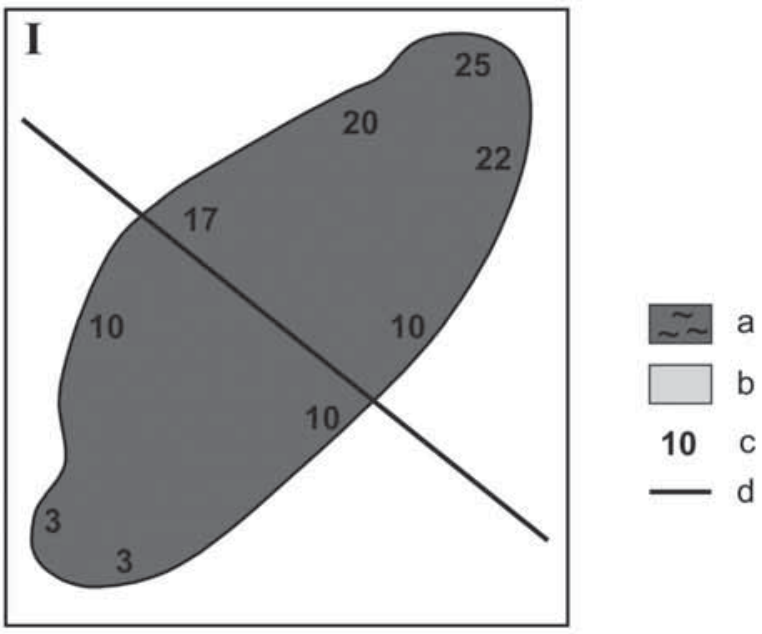

\section{II}

m. a.s.I.
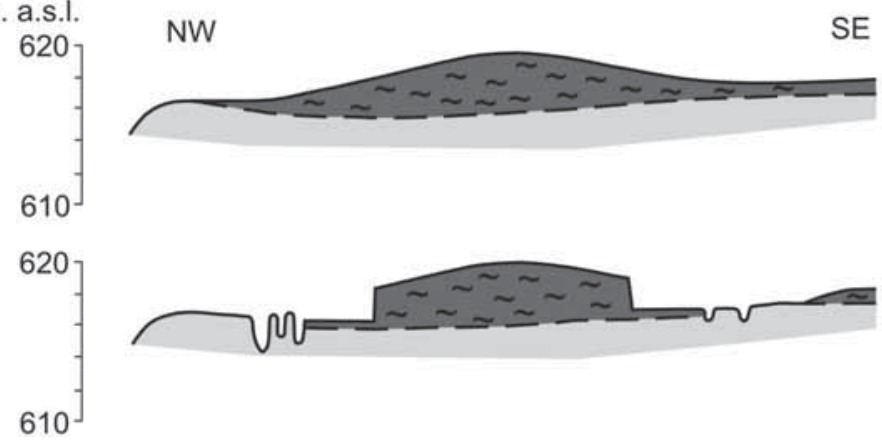

$\left.\begin{array}{r}\left.{ }^{620}\right] \\ - \\ 610^{-}\end{array}\right]$
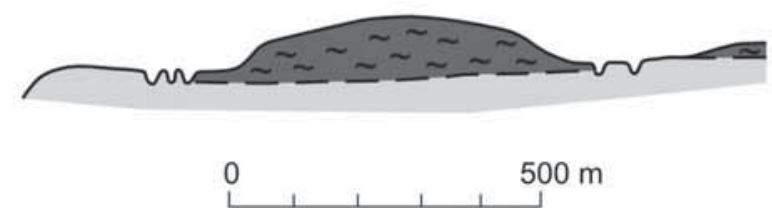

Figure 7. Current inclination $\left[^{\circ}\right]$ of peat scarp slopes around the remnant of peat dome of the Bór na Czerwonem peat bog, No 16 in Fig. 1 (I).

Cross-profiles through the peat bog and surroundings showing probable topography of the area prior to human impact on the peat bog and changes in relief of post-peat areas over the last 55 years (II):

$\mathrm{a}$ - peat deposit, $\mathrm{b}$ - clayey substratum, $\mathrm{c}$-inclination of peat scarp slopes $\left[^{\circ}\right]$ in chosen places, $\mathrm{d}$ - location of profile line

that are 11-30 years old are dominated by phase "d". Scarps that are 31-60 years old and those over 60 years old are dominated by phases "e" and "f $\mathrm{f}$ ".

In the early stages of peat bog scarp development when vegetation is not yet fully entrenched, peat is washed away by heavy rainfall. Likewise, spring snowmelt causes peat flows into hollows at the base of the scarp. The role of wind in the dislocation of dry peat particles is negligible compared to the role of rainfall and snowmelt. Of the ge- 
omorphological processes mentioned, only the intensity of peat flow in the early spring depends on scarp exposure. The intensity of this process is the greatest on scarps facing south and southwest and the smallest on scarps facing north and northeast. This explains the high frequency of occurrence of scarps in their earliest phase of development ("a") on the northern and northeastern sides of peat domes in the Orawa - Nowy Targ Ba$\sin (30 \%$ and $31 \%$ of total length) and the low frequency of occurrence on the southern and southwestern side $(1 \%$ and $0 \%$ of total length). The frequency of occurrence of scarps in their most advanced phase of development (" $\mathrm{f}$ ") is greatest on the southern and southwestern sides of peat domes (40\% and $46 \%$ of total length). Phase " $\mathrm{f}$ " has not been detected on the northern and northeastern sides at all. This is illustrated by the differences in scarp slope around the remnants of the peat dome in Bór na Czerwonem (Fig. 7). The same is true in the Bieszczady Mountains. Phase "f" scarps are concentrated on the southern, southwestern and western sides of peat domes $(20 \%, 27 \%, 22 \%$ of total length, respectively). The occurrence of short segments of these scarps on the opposite side of peat domes suggests a longer period of evolution compared to that in the Orawa - Nowy Targ Basin. This is also confirmed by the absence of phase "a" scarps on the northern and northeastern sides of peat domes in the Bieszczady Mountains.

\section{SHALLOWING AND DISAPPEARANCE OF PEAT HOLLOWS AND DRAINAGE DITCHES IN POST-PEAT AREAS}

Changes in relief in post-peat areas include the flattening of scarps as well as peat hollows and drainage ditches that become shallow or disappear altogether. Hollows in post-peat areas are the result of uneven peat extraction, which leads to a residual peat layer of varying thickness. In the process of peat extraction, landowners fill peat hollows with residual vegetation removed from the peat dome. In the Orawa - Nowy Targ Basin, peat hollows at the base of the scarp are quickly filled with peat mud. In some cases, this process takes place within a few years. Peat hollows located farther away from the scarp tend to take longer to fill (see Fig. $6)$. Three years following their formation, water-filled hollows become overgrown with peat moss, which masks relief in post-peat areas by creating the impression of a level surface. Drainage ditches become shallow in an analogous way at the base of scarps, above felled trees, above beaver dams and above man-made dams halting water flow away from peat bogs. Drainage ditches in peat bogs in the Bieszczady Mountains today are entirely covered by vegetation and had started to become shallow starting in the late 1980s. This explains why it is difficult to detect these landforms and aerial photographs must be used for this purpose. In the Orawa - Nowy Targ Basin, drainage ditches in the external younger post-peat zone and in older post-peat zones have not been dredged in almost 20 years. This is why they are so shallow at a number of locations and have been overgrown with vegetation. Still, they are more visible than old drainage ditches in peat bogs in the Bieszczady Mountains.

\section{STREAM CHANNEL REGULATION IN POST-PEAT AREAS AND THEIR SURROUNDINGS, AND ITS GEOMORPHOLOGICAL AND HYDROGRAPHIC EFFECTS}

Many streams found close to peat bogs in the two study areas as well as their tributaries draining post-peat areas have been regulated, which was designed to partially dry wetlands being used for agricultural purposes. Another reason for the stream regulation was the desire to dry peat extraction areas. In the Bieszczady Mountains, the goal was to completely dry peat bogs and turn them into pastures (Łajczak, 2006a,b, 2011). More than half the length of the streams in peat bogs and adjacent areas was regulated by straightening out channels and widening them. In effect, narrow and relatively deep channels of meandering streams were turned into shallow and wide channels with a larger gradient and a gravel bed. Natural streams that used to flow around peat domes 
became drainage channels (girdling ditches) encircling lagg fens or were linked to larger regulated streams nearby. The regulation of streams initially led to accelerated drainage from peat bogs. The creation of drainage ditches further accelerated the drying of post-peat areas. When peat extraction came to an end, exposing poorly permeable clayey base material, and stream channels were straightened, widened and afforded a larger gradient, the intensity of runoff during floods increased. This resulted in the creation of gravel-bottom stream channels with a local tendency for aggradation. This was true even in the case of small streams. A second effect was short-term flooding of low-lying areas in the vicinity of peat bogs but outside of post-peat areas. Streams with straightened channels tend to undercut banks, which prompts them to start meandering once again. When drainage ditches become shallow and overgrown with vegetation, the water retention capacity of former peat bogs increases. This leads to lower flood stages on local streams.

In the Bieszczady National Park, several dozen small earth dams were recently built on streams flowing around peat bogs and in the general vicinity of six peat bogs. The resulting reservoirs play an important ecological role in addition to their traditional role as storage pools (Lajczak, 2011). The reservoirs continue to function, however, they are slowly being filled by silt. In three other post-peat areas, small land-locked reservoirs were created in depressions reaching the clayey base material.

\section{EFFECTS OF BEAVER ACTIVITY}

In the Bieszczady National Park, numerous beaver-made reservoirs occur in the vicinity of five peat bogs in recent years. Beavers build dams on peat bog fringed streams and larger streams in the general area. The dams lead to the partial or complete flooding of large areas close to peat bogs. The same is true of older post-peat areas and younger post-peat areas (Łajczak, 2011). In 2010, a small part of the Wolosate peat dome (No 14 in Fig. 1) was also flooded.
Other beaver-related geomorphological effects include sub-surface channels leading to stream banks, deeper stream channels and new stream channels with depressions forming downstream of dams. Beaver-built sub-surface channels often collapse creating numerous hollows more than $0.5 \mathrm{~m}$ deep in the vicinity of streams. Fine sediments supplied by streams accumulate in beaver-built reservoirs. Once a reservoir is abandoned by beavers, the dam falls apart and the flow of water erodes sediments. In effect, these areas serve as wetlands (Stopka, 2011).

\section{A DECREASE IN THE VOLUME OF PEAT DEPOSITS DUE TO HUMAN ACTIVITY}

The quantity of peat in both study areas was estimated for three time periods - prior to human activity at the end of the Middle Ages, during the middle of the $19^{\text {th }}$ century, and at the beginning of the $21^{\text {st }}$ century. In the Orawa - Nowy Targ Basin, the quantity of peat was estimated in terms of the average thickness of the peat layer in peat domes during each of the three periods of interest $(4 \mathrm{~m})$. The average thickness of the peat layer in younger post-peat areas was estimated to be about $0.2 \mathrm{~m}$. The average thickness of the peat layer in neighbouring low peat bogs was estimated to be $0.2 \mathrm{~m}$ for the first two periods of interest, while today it is estimated to be $0.5 \mathrm{~m}$, as peat layers with a smaller thickness had been extracted earlier. Other explanations include the burning of peat and its liquidation as part of agricultural activity. In the Bieszczady Mountains, the average thickness of the peat layer in peat domes is $2.5 \mathrm{~m}$, while in post-peat areas it is $0.4 \mathrm{~m}$. Finally, in low peat bogs it is $0.2 \mathrm{~m}$. The total area of peat domes, post-peat areas and low peat bogs for all time periods of interest and both study areas have been listed earlier.

The volume of the peat deposits in the Polish part of the Orawa - Nowy Targ Basin prior to human activity has been estimated to be $170 \mathrm{mln} \mathrm{m}^{3}$, of which $140 \mathrm{mln} \mathrm{m}^{3}$ was found in large peat domes and $30 \mathrm{mln} \mathrm{m}^{3}$ was found in even larger low peat bogs. In the Bieszczady Mountains, the volume of peat at the time was over 100 times smaller, 
with $1.4 \mathrm{mln} \mathrm{m}^{3}$ in peat domes and $0.1 \mathrm{mln}$ $\mathrm{m}^{3}$ in low peat bogs. In the Orawa - Nowy Targ Basin, the area of peat bogs decreased at the fastest rate in the middle of the $19^{\text {th }}$ century. At the time, peat deposits became smaller by $28 \%$, which left about $122 \mathrm{mln}$ $\mathrm{m}^{3}$ in place. Peat domes stored $82 \%$ of the peat at the time. Low peat bogs stored $16 \%$, while $2 \%$ were found in post-peat areas. The current volume of peat in the Orawa - Nowy Targ Basin is $79.5 \mathrm{mln} \mathrm{m}^{3}$. This is less than half the peat volume present in the area when large-scale settlement began to take place in the $13^{\text {th }}-17^{\text {th }}$ centuries. Today, peat domes store $65 \%$ of peat deposits. Low peat bogs store $31 \%$, while post-peat areas store $4 \%$. In the Polish part of the Bieszc- zady Mountains, the volume of peat found today is $1.27 \mathrm{mln} \mathrm{m}^{3}$. This is 63 times less peat than in the Orawa - Nowy Targ Basin. The volume of peat in the Bieszczady Mountains has decreased by a mere $16 \%$ since the establishment of villages in the region in the $17^{\text {th }}$ century. Despite the decreasing area of peat bogs, peat domes store $93 \%$ of the peat. Low peat bogs store $5 \%$, while post-peat areas store $2 \%$. The decrease in the volume of peat deposits mirrors the decrease in the area of peat bogs. The total volume of peat lost during the last several centuries in the two study areas is about 91 $\mathrm{mln} \mathrm{m}^{3}(53 \%)$. As much as $99.7 \%$ of this loss occurred in the peat bogs of the Orawa Nowy Targ Basin.
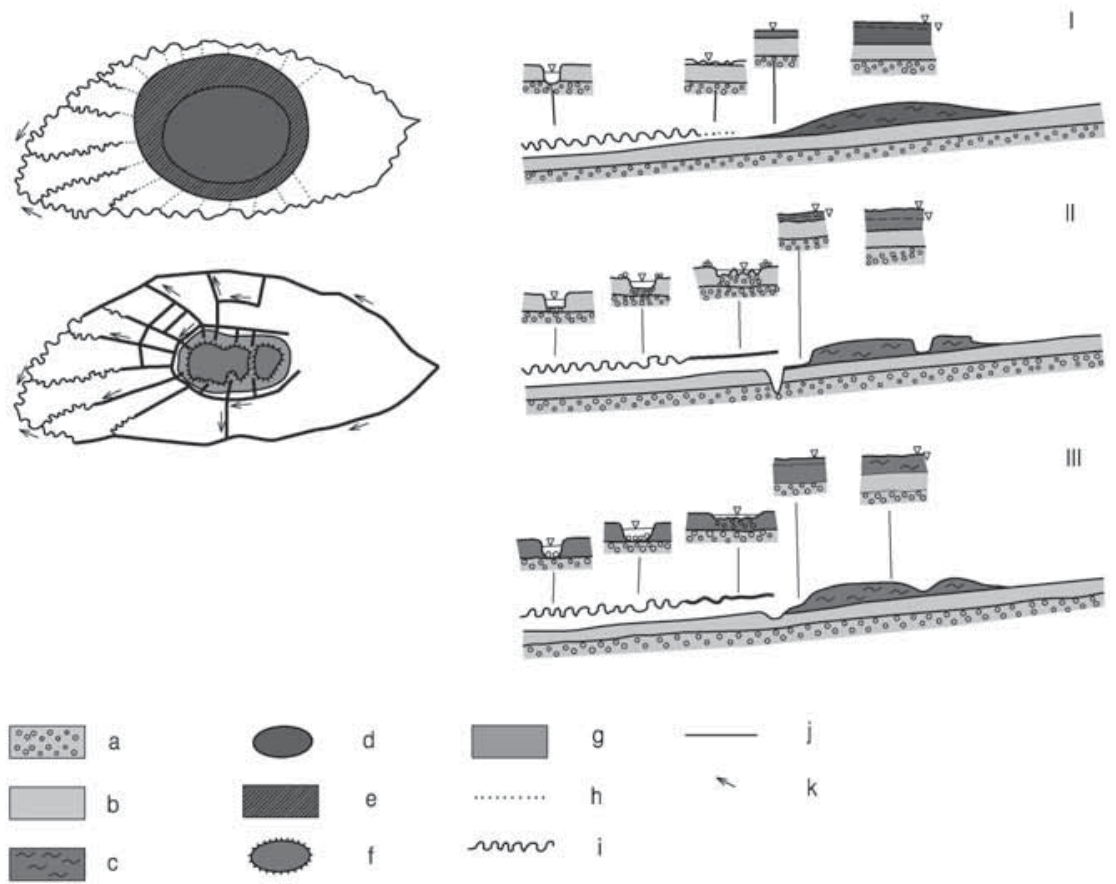

Figure 8. Scheme of changes in raised bog relief under human impact

State of peat bog: I - prior to human activity, II - prior to the end of peat extraction and drying, III - during the initial stages of restoration of peat bog remnants. A - plan, B - the longest cross-profile: a - gravel substratum, b - clayey substratum, c - peat deposit, $\mathrm{d}$ - former horizontal range of peat dome, e - former lagg fen zone, $\mathrm{f}$ - current remnant of peat dome, $\mathrm{g}$ - younger post-peat area, $\mathrm{h}$ - water seepages from peat bog as sources of streams, $\mathrm{i}$ - unregulated (meandering) streams, $\mathrm{j}$ - regulated streams and drainage ditches, $\mathrm{k}$ - drainage directions. Fluctuations of water level in stream channels and in peat deposit are presented 


\section{LANDSCAPE DEVELOPMENT PROGRESSION OF AN ANTHROPOGENICALLY DEGRADED RAISED BOG}

Fig. 8 illustrates the aforesaid changes in raised bog relief. The figure shows the state of the peat bog prior to human activity (I), prior to the end of peat extraction and drying (II), and during the initial stages of restoration of peat bog remnants (III). In period I, peat domes were larger than today and were surrounded by wetlands (lagg fens) and were drained by meandering streams. The source of the streams was water seepage from peat bogs. Meandering streams possessed narrow and relatively deep channels cutting into the layer of clay beneath peat bogs and the even deeper layer of gravel. In period II, the amount of area lost by the peat dome and former wetland fringe can be identified in terms of older and younger post-peat areas. Stream channels in the general area have been regulated and drainage ditches dug. Partial or full peat extraction taking place primarily in the domes' fringe zone has produced major changes in peat bog relief and has substantially reduced peat bog water content. The increased density of drainage ditches in the area surrounding the remnants of peat domes has led to further drying of the peat bog. An unintended consequence of stream regulation are shallower and wider channels that evolve into braided channels with a local tendency to accumulate material. In period III, with peat extraction having been halted in most peat bogs and drainage ditch maintenance having been abandoned, more advanced post-extraction scarp relief changes are being observed. At the same time, hollows and ditches across post-peat areas are becoming more shallow and overgrown with vegetation. In effect, geomorphological contrasts in post-peat areas become attenuated.

\section{DISCUSSION AND CONCLUSIONS}

Changes in peat bog relief due to human activity are usually explained in the research literature as the result of sheep and cattle grazing, burning of peat deposits and drainage of peat bogs. Peat bog erosion is normally mentioned in the literature but few studies cover contemporary changes in peat bog relief in depth. This type of approach is taken by British researchers (Bower, 1961; Evans, 1989; Shaw et al., 1997; Bragg and Tallis, 2001). In Poland, human impact on raised bog relief is usually limited to peat extraction and drying. The expansion of post-peat areas at the expense of peat domes continues to be driven by the hand-cutting of peat by local landowners. The machine-cutting of peat over large areas and the drying of peat deposits in areas with drainage systems are also common occurrences. Hand-cutting is commonly practiced in the Carpathian Mountains and used to be practiced in the Sudety Mountains. Large peat extraction areas and post-peat areas as well as large drained peat bogs are often found in northern Poland (e.g., Mirska, 1956; Churski, 1993; Koczur, 1996; Łajczak, 2002, 2006a, 2011).

Peat bog landforms in Great Britain and Ireland created as a result of the machine-cutting and hand-cutting of peat tend to possess sharp relief over long periods of time (Cooper and McCann, 1995; Latocha, 2011). This includes scarps and peat hollows. The abandonment of sheep grazing does not quickly lead to gentler landforms either (Rawes, 1983). Compared to the slow changes in post-peat relief in Great Britain, the rate of change in scarp and hollow relief across raised bogs in the Polish Carpathian Mountains appears to be quite large. Latocha (2011) has described post-extraction depressions in blanket bogs in Ireland that are still ringed by vertical scarps, although peat extraction has been abandoned over 50 years ago. The rapid encroachment of grass favours peat bog scarp stabilization. However, older peat hollows are much more shallow than younger peat hollows, as their bottoms are always wet. In the Carpathian study area, peat bog scarps take longer to become overgrown with bush-type plants and pine and peat moss initially invades only peat hollows and drainage ditches (Korczyńska, 1952; Mirska, 1956; Zembrzuski, 1995; Koczur, 
1996; Łajczak, 2006a). The burning of peat was a key factor behind the decline of blanket bogs in highland and mountain areas in the British Isles (Rhodes and Stevenson, 1997) and the decline of raised bogs in the Polish Carpathians ever since the onset of the age of settlement in the $17^{\text {th }}$ century. The burning of peat ceased to be a key factor during the early $20^{\text {th }}$ century (Lajczak, 2006a).

Raised bogs in the Orawa - Nowy Targ Basin and the Bieszczady Mountains, which had formed across fluvial and fluvioglacial landforms with a small gradient, are characterized by weak mass movements that today affect only post-extraction scarps and their base. Blanket bogs in Great Britain and Ireland cover entire mountaintops and slopes (Carling, 1986; Dykes and Warburton, 2007), while peat bog landforms in Poland tend to be very small. Peat bog scarps in the "b" phase of development experience micro-slides and local peat flows may occur up to phase "d" (see Fig. 6). In light of the classification system of mass movements in peat bogs (Dykes and Warburton, 2007), sliding peat packets on the scarps of interest may be designated bog slides, while peat flows may be designated bogflows. The second type of mass movement affects larger areas including filled peat hollows in post-peat areas. This type of mass movement lasts longer and results in the complete coverage of scarps and their base with vegetation. In both types of mass movements, peat from the entire catotelm cross-section is shifted. In studied areas, the volume of peat shifting per $100 \mathrm{~m}$ of scarp ranges from 5 to $15 \mathrm{~m}^{3}$. This is as much as six orders of magnitude less than that for blanket bogs in the British Isles (see Dykes and Warburton, 2007).

The remnants of peat domes in the Polish part of the Orawa - Nowy Targ Basin and the Bieszczady Mountains account for $0.7 \%$ of the number of identified raised bogs in Poland. However, they occupy an area of 1,347 ha, which constitutes $2.2 \%$ of the area of all raised bogs in Poland (see Żurek, 1983; Ilnicki and Żurek, 1996). The area of peat domes plus the area of younger post-peat areas account for $4.3 \%$ of the total area of all raised bogs in Poland. However, when the remnants of low peat bogs are included in the calculation, the total area of peat domes and younger post-peat areas accounts for only $0.6 \%$ of the total area of all peat bogs in Poland. The studied remnants of peat domes account for $0.13 \%$ of the volume of all peat bogs in Poland. When post-peat areas are considered in the calculation, the target value increases to $0.14 \%$.

Despite the large number of advanced studies on the human impact on peat bogs in Poland, more studies are recommended, especially once that would consider all forms of human activity in raised bog areas. It is recommended that changes in affected peat bogs be monitored, especially peat bogs in the third phase of development. This type of research could be used to assess the rate of peat bog restoration. This would be especially valuable with respect to peat bogs that are in need of formal nature protection.

\section{ACKNOWLEDGEMENTS}

The author would like to thank the two anonymous reviewer for critical comments on the manuscript.

\section{REFERENCES}

Bindler, R. (2006), Mires in the past - looking for the future: Geochemistry of peat and the analysis of past environmental changes, Global and Planetary Changes, 53: 209-221.

Bower, M.M. (1961), The distribution of erosion in blanket peat bogs in the Pennines, Transactions of the Institute of British Geographers, 29: $17-30$.

Bragg, O.M. and Tallis, J.H. (2001), The sensitivity of peat-covered upland landscapes, Catena, 42: 345-360.

Carling, P.A. (1986), Peat slides in Teesdale and Weardale, Northern Pennines, July 1983: description and failure mechanisms, Earth Surface Processes and Landforms, 11: 193-206.

Churski, Z. (1993), Antropogeniczne i naturalne tendencje rozwoju jezior i mokradet w Polsce 
[Anthropogenic and natural tendencies in lakes and marshes development in Poland], in Dynowska, I. (ed.), Przemiany stosunków wodnych $w$ Polsce $w$ wyniku procesów naturalnych $i$ antropogenicznych [Changes in water conditions in Poland impacted by natural and anthropogenic processes], Wydawnictwo Uniwersytetu Jagiellońskiego, Kraków, pp. 55-210.

Coggins, A.M., Jennings, S.G. and Ebinghaus, R. (2006), Accumulation rates of heavy metals: lead, mercury and cadmium in ombrothrophic peatlands in the west of Ireland, Atmospheric environment, $40: 260-278$.

Cooper, A. and McCann, T. (1995), Machine Peat Cutting and Land Use Change on Blanket Bog in Northern Ireland, Journal of Environmental Management, 43: 153-170.

Dykes, A.P. and Warburton, J. (2007), Mass movements in peat: A formal classification scheme, Geomorphology, 86: 73-93.

Evans, R. (1989), Erosion studies in the Dark Peak. North of England Soils Discussion Group, Proceedings, 24: 39-61.

Fiałkiewicz-Kozieł, B. (2009), Dynamika zmian zanieczyszczenia metalami ciężkimi na przyktadzie wybranych torfowisk wysokich Kotliny Orawsko-Nowotarskiej [The dynamics of pollution by heavy metals in chosen raised bogs in the Orawa-Nowy Targ Basin], unpublished PhD thesis, University of Silesia, Faculty of Biology and Environment Protection, Katowice.

Ilnicki, P. and Żurek, S. (1996), Peat resources in Poland, in Lappalainen, E. (ed.), Global peat resources, International Peat Society, Geological Survey of Finland, pp. 119-125.

Jasnowski, M. (1975), Torfowiska i tereny bagienne $w$ Polsce [Peatbogs and marshes in Poland], in Kac, I. (ed.), Bagna kuli ziemskiej [Marshes of the world], Wydawnictwo Naukowe PWN, Warszawa, 356-390.

Jostowa, W. (1963), Materiały do zagadnień gospodarki chłopskiej w „Borach” Orawskich [Materials concerning the problem of peasant economy in the region of Orawa peatbogs], Lud, 2: 503-554.

Kaule, G. and Göttlich, K. (1976), Begriffsbestimmungen anhand der Moortypen Mitteleuropas, Moor- und Torfkunde. E. Schweizerbart sche Verlagsbuchhandlung, Stuttgart, 1-28.
Koczur, A. (1996), Zmiany powierzchni i stanu zachowania torfowisk wysokich koło Ludźmierza w ostatnim stuleciu [Changes in the area and state of preservation of raised bogs near Ludźmierz during the last century], Chrońmy Przyrode Ojczysta, 5: 25-38.

Korczyńska, E. (1952), Bory i Puścizny Podhala i Orawy [Peatbogs and barren of Podhale and Orawa], Prace Zaktadu Dendrologii i Pomologii w Kórniku, 240-259.

Latocha, A. (2011), Antropogeniczne zmiany środowiska przyrodniczego obszarów górskich w Irlandii na przyktadzie Parku Narodowego Glenveagh [Anthropogenically influenced changes in natural environment of mountainous areas in Ireland, an example of Glenveagh National Park], in Lajczak, A. (ed.), Geomorfologiczne skutki antropopresji. Przyktady $z$ różnych stref morfoklimatycznych świata [Geomorphological consequences of human activity. Examples from different morphoclimatic zones of the world], Wydawnictwo Wydziału Nauk o Ziemi Uniwersytetu Śląskiego, Sosnowiec (in print).

Łajczak, A. (2002), Antropogeniczna degradacja torfowisk orawsko-podhalańskich [Anthropogenic degradation of the Orawa-Podhale peatbogs], Czasopismo Geograficzne, 73 (1-2): 27-61.

Łajczak, A. (2005), The role of biogenic accumulation and peat excavation in geomorphological development of the Orawa-Nowy Targ Basin, West Carpathian Mts., Geomorfologický Sbornik, 4: 97-100.

Łajczak, A. (2006a), Torfowiska Kotliny Orawsko-Nowotarskiej [Peatbogs of the Orawa-Nowy Targ Basin], Wydawnictwo Instytutu Botaniki im. W. Szafera, PAN, Kraków, 1-147.

Łajczak, A. (2006b), Raised bog Bór na Czerwonem (Podhale, South Poland) - development, degradation, renaturalisation, Nature Conservation, 62: 89-103.

Łajczak, A. (2011), Plan Ochrony Bieszczadzkiego Parku Narodowego [Management Plan of the Bieszczady National Park], unpublished materials, Dyrekcja Bieszczadzkiego Parku Narodowego [Directorate of the Bieszczady National Park], Ustrzyki Górne.

Mallik, A.U., Gimingham, C.H. and Rahman, A.A. (1984), Ecological effects of heather 
burning: I. Water infiltration, moisture retention and porosity of surface soil, Journal of Ecology, 72: 767-776.

Mirska, A. (1956), O możliwościach gospodarczego wykorzystania nieużytków potorfowych Kotliny Nowotarskiej [On the chance of economic use of the post-peat areas within the Nowy Targ Basin], Chronmy Przyrode Ojczysta, 2: 3-9.

Myślińska, E. (2001), Grunty organiczne i laboratoryjne metody ich badania [Organic deposits and laboratory methods for their testing], Wydawnictwo Naukowe PWN, Warszawa.

Rawes, M. (1983), Changes in two high altitude blanket bogs after cessation of sheep grazing, Journal of Ecology, 71: 219-235.

Rhodes, N. and Stevenson, A. (1997), Palaeoenvironmental evidence for the importance of fire as a cause of erosion of British and Irish blanket peats, in Tallis, J.H., Meade, R. and Hulme, P.D. (eds.), Blanket Mire Degradation: Causes, Consequences and Challenges. Macaulay Land Use Research Institute, Aberdeen, 64-78.

Shaw, S., Wheeler, B. and Backshall, J. (1997), Review of effects of burning and grazing of blanket bogs - conservation issues and conflicts, in Tallis, J.H., Meade, R. and Hulme, P.D. (eds.), Blanket Mire Degradation: Causes, Conse- quences and Challenges. Macaulay Land Use Research Institute, Aberdeen, 174-182.

Stopka, R. (2011), Geomorfologiczne skutki działalności bobra europejskiego Castor fiber w dolinie górnego Sanu [Geomorphic effects of European beaver Castor fiber in the valley of upper San River], Roczniki Bieszczadzkie, 19 (in print).

Zembrzuski, J. (1994), Ochrona torfowisk Orawy i Podhala jest konieczna i możliwa [Protection of peatbogs in the area of Orawa and Podhale is needed and feasible], Wydawnictwo Ligi Ochrony Przyrody, Klub Ekologiczny Karpaty, 7-14.

Żurek, S. (1983), Stan inwentaryzacji torfowisk w Polsce [State of stock-taking of peat-bogs in Poland], Wiadomości Melioracyjne i Łakarskie, 7: 210-215.

Żurek, S. (1987), Złoża torfowe w Polsce na tle stref torfowych Europy [The peat deposits of Poland against the peat zones of Europe], Dokumentacja Geograficzna 4, Instytut Geografii i Przestrzennego Zagospodarowania (IGiPZ), PAN: 1-84.

Paper first received: May 2011

In final form: August 2011 